\title{
A SURVEY OF ALUMINIUM ACCUMULATION IN EUMACHIA (RUBIACEAE)
}

\author{
I. M. Turner ${ }^{1,2}$, F. Q. Brearley ${ }^{3}$, L. A. Trethowan ${ }^{3,4} \&$ T. M. A. Utteridge ${ }^{4}$
}

A useful character for spotting specimens of the pantropical Rubiaceae genus Eumachia is the leaves drying green. The physiological reasons for this are unresolved. We investigated whether the phenomenon is related to the accumulation of aluminium. Samples of foliage from herbarium specimens of nine species of Eumachia (Rubiaceae), including collections from Asia-Pacific, Africa and the Americas, were analysed for elemental concentrations. For comparison, specimens of the closely related genera Psychotria and Palicourea from similar geographical regions were also analysed. Two species, Palicourea violacea (Panama) and Psychotria pallens (Brazil) were found to be aluminium hyperaccumulators ( $\geq 1 \%$ Al by dry weight), with a third species, Eumachia collina (from New Caledonia), falling just short of the threshold with $0.99 \%$ Al. Aluminium accumulation ( $\geq 0.4 \%$ Al by dry weight) occurs but is infrequent among species of Eumachia and appears less common than in the close relative Palicourea. Aluminium accumulation also appears patchy in Psychotria sensu stricto. It seems unlikely that herbarium greenness in Eumachia is directly related to aluminium accumulation.

Keywords. Hyperaccumulation, Palicourea, Palicoureeae, Psychotria, Psychotrieae, shrubs. Received 1 October 2019 Accepted 22 September 2020 Published 9 March 2021

\section{Introduction}

The rubiaceous genus Eumachia, despite being large (more than 100 species) and almost pantropical (Taylor et al., 2017), is poorly known to tropical botanists. This is readily explained because nearly all the species were formerly included in Psychotria, probably the most species-rich genus of woody plants (Davis et al., 2001). Added to this, once plant taxonomists began to separate out this group from Psychotria various names, including Chalaziella and Margaritopsis (Andersson, 2001; Barrabé et al., 2012), were used before Eumachia was determined to be the correct one.

Species of Eumachia are typically shrubs or small trees with interpetiolar stipules that become hard and straw-coloured and often fragment from the margin, and pyrenes with marginal preformed germination slits (Taylor et al., 2017). Another character that can be useful in determining herbarium material is that in most species of Eumachia the leaves

${ }^{1}$ Singapore Botanical Liaison Officer, Royal Botanic Gardens, Kew, Richmond, Surrey TW9 3AB, England, UK. E-mail: i.turner@kew.org.

${ }^{2}$ Herbarium, Singapore Botanic Gardens, National Parks Board, 1 Cluny Road, Singapore 259569.

${ }^{3}$ Department of Natural Sciences, Manchester Metropolitan University, Chester Street, Manchester M1 $5 \mathrm{GD}$, England, UK.

${ }^{4}$ Identification and Naming, Science Directorate, Royal Botanic Gardens, Kew, Richmond, Surrey TW9 $3 A B, U K$. 
dry distinctly green. Although there are species of true Psychotria that dry green, most dry various shades of red-brown or grey-brown.

The reason for the unusual colour of dry leaves in Eumachia species does not seem to be known. One possibility is that it is related to the accumulation of particular elements in the plant tissues. Given the extensive distribution of the genus and the absence of a common association of the species with unusual geological substrates such as ultramafics, aluminium accumulation on the typically acid and aluminium-rich soils of the lowland wet tropics is considered the most likely explanation. Chenery (1948) noted that leaves drying yellowish green were common among aluminium accumulators. There is a report, based on a semiquantitative chemical assay, of Eumachia acuifolia (C.Wright) Delprete \& J.H.Kirkbr., a species from Cuba, being an aluminium hyperaccumulator (Jansen et al., 2000, as Margaritopsis nudiflora K.Schum.). To investigate this further, we measured elemental concentrations in leaf material from herbarium specimens. To provide comparators, we sought to analyse material from species of Psychotria sensu stricto.

\section{Materials and methods}

The material for investigation all came from specimens in the collection of the Royal Botanic Gardens, Kew (K). Samples were chosen by going through the herbarium cupboards searching for Eumachia specimens with extra material of mature leaves loose in packets. These were then sampled for destructive analysis of selected elements including aluminium. Species from across the geographical range of the genus were sought. Specimens obviously from upper montane systems were avoided. To provide a comparator for each Eumachia specimen, a specimen of a Psychotria species from a similar region was also sought for use in the analysis. It transpired that for two of the American Psychotria species selected, the herbarium curation had not caught up with recent transfers to Palicourea, a large Neotropical genus. Therefore, the comparator taxon to Eumachia included species of both Psychotria and Palicourea. In total 18 samples were analysed. The specimens sampled are listed in the Appendix.

Leaf samples obviously muddy or otherwise exhibiting soil accretion were excluded. It is possible that some of the specimens used may have been treated with mercuric chloride as a prophylactic against insect pests, or contaminated with mercury from treated specimens. This is not likely to influence concentrations of aluminium, however.

The leaf samples (c.100 mg each) were digested in $10 \mathrm{~mL}$ of concentrated nitric acid by using a MARSXpress microwave (CEM, Matthews, NC, USA) and made up to $100 \mathrm{~mL}$ in ultrapure (18 M $\Omega$ ) deionised water. Total $\mathrm{Al}, \mathrm{Ca}, \mathrm{Cd}, \mathrm{Co}, \mathrm{Cr}, \mathrm{Cu}, \mathrm{Fe}, \mathrm{K}, \mathrm{Mg}, \mathrm{Mn}, \mathrm{Na}, \mathrm{Ni}, \mathrm{P}$ and $\mathrm{Pb}$ concentrations were quantified using an iCAP 6300 Duo inductively coupled plasma optical emission spectrometer (Thermo-Finnegan, San Jose, CA, USA). Reference material (LGC 7162, Strawberry Leaves) was analysed alongside the samples. These showed good recovery for the certified elemental concentrations, but Al recovery was considerably (62\%) lower than the indicative (non-certified) concentration of $1000 \mu \mathrm{g} / \mathrm{g}$. This may mean that 
our results for $\mathrm{Al}$ are lower than the true values, but they are likely to be a good reflection of relative concentrations between species.

In a statistical analysis of a large data set, Metali et al. (2011) found that a threshold value of $2300-3900 \mu \mathrm{g} \mathrm{Al} / \mathrm{g}$ leaf dry mass was required in tropical species to distinguish aluminium accumulators from non-accumulators. To be conservative, we used a minimum value of $4000 \mu \mathrm{g} / \mathrm{g}$ or $0.4 \%$ for aluminium accumulators and $10,000 \mu \mathrm{g} / \mathrm{g}$ or $1 \%$ for hyperaccumulators.

To visualise the complete data set, a principal components analysis (PCA) was run using the software R (R Core Team, 2020).

\section{Results}

Evidence of aluminium accumulation ( $>0.4 \%$ by dry weight) was found for four species (Table, Figure 1). These were Palicourea conephoroides (Rusby) C.M.Taylor, Palicourea

Table. Aluminium concentration in the leaves of 18 species from three genera in the Rubiaceae ${ }^{a}$

\begin{tabular}{llc}
\hline Species & Location & Aluminium $(\mu \mathrm{g} / \mathrm{g}$ leaf dry mass $)$ \\
\hline Eumachia abrupta & Tanzania & 1248 \\
Psychotria leucopoda & Tanzania & 66 \\
Eumachia boliviana & Peru & 140 \\
Palicourea conephoroides & Peru & $5515^{\mathrm{b}}$ \\
Eumachia cephalantha & Brazil & 667 \\
Psychotria pallens & Brazil & $29,628^{\mathrm{c}}$ \\
Eumachia collina & New Caledonia & $9910^{\mathrm{b}}$ \\
Psychotria frondosa & New Caledonia & 329 \\
Eumachia damasiana & New Guinea & 129 \\
Psychotria beaufortiensis & New Guinea & 1141 \\
Eumachia leptothyrsa & New Guinea & 174 \\
Psychotria lolokiensis & New Guinea & 2016 \\
Eumachia microdon & Panama & 66 \\
Palicourea violacea & Panama & $33,477^{\mathrm{c}}$ \\
Eumachia montana & Sumbawa & 197 \\
Psychotria sp. & Sumbawa & 296 \\
Eumachia obanensis & Cameroon & 1368 \\
Psychotria hypsophila & Cameroon & 368 \\
\hline For & &
\end{tabular}

${ }^{a}$ For species authorities, see the Appendix.

${ }^{b}$ Above the $4000 \mu \mathrm{g} / \mathrm{g}(0.4 \%)$ threshold for aluminium accumulation.

c Above the $10,000 \mu \mathrm{g} / \mathrm{g}(1.0 \%)$ threshold for aluminium hyperaccumulation. 


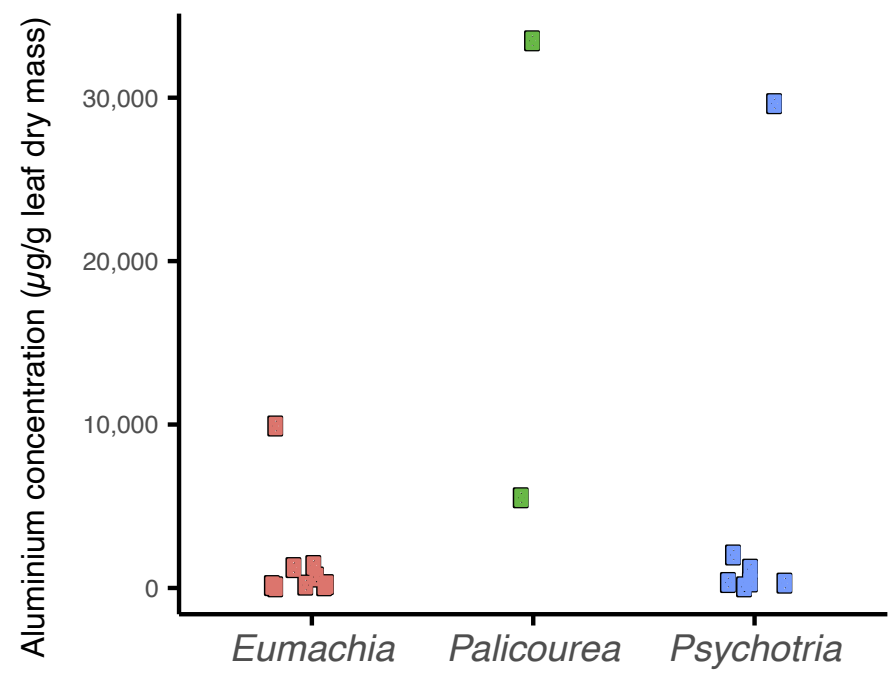

Figure 1. Aluminium concentration in the leaves of 18 species from three Rubiaceae genera.

violacea (Aubl.) A.Rich. and Psychotria pallens Gardner from the Neotropics, and Eumachia collina (Labill.) Barrabé, C.M.Taylor \& Razafim. from New Caledonia. Palicourea violacea and Psychotria pallens had Al concentrations well above the threshold for hyperaccumulation, with Al concentration in Eumachia collina (0.99\%) falling just short.

No consistent pattern emerged from the comparison of Eumachia species with Psychotria/Palicourea in terms of foliar Al concentration. For the Asia-Pacific and Neotropical pairs, Eumachia species generally had lower Al concentrations than Psychotria/ Palicourea, but for the two African comparators the trend was reversed.

The first two axes of the PCA (Figure 2) accounted for $48 \%$ of the variance in the data. The first axis (principal component $1 ; 32 \%$ of variance explained) correlated positively with Al concentration and negatively with the concentration of most of the other elements (see Figure 2B). The second axis (principal component 2; $16 \%$ of variance) more effectively discriminated between Eumachia and Psychotria/Palicourea. This axis opposed foliar concentrations of $\mathrm{K}, \mathrm{P}$ and $\mathrm{Mg}$ with those of $\mathrm{Mn}, \mathrm{Pb}$ and $\mathrm{Al}$ (see Figure 2B). Eumachia species generally had a higher score on this axis, with Psychotria and Palicourea species at the lower end, although there was some overlap (see Figure 2A).

\section{Discussion}

Our sample size was small and unreplicated within species, but some patterns were evident. Of the nine species of Eumachia analysed, only one (Eumachia collina from New Caledonia) was found to be an aluminium accumulator, although it very nearly qualified as a hyperaccumulator. Although this adds to the previous record of this phenomenon, from 

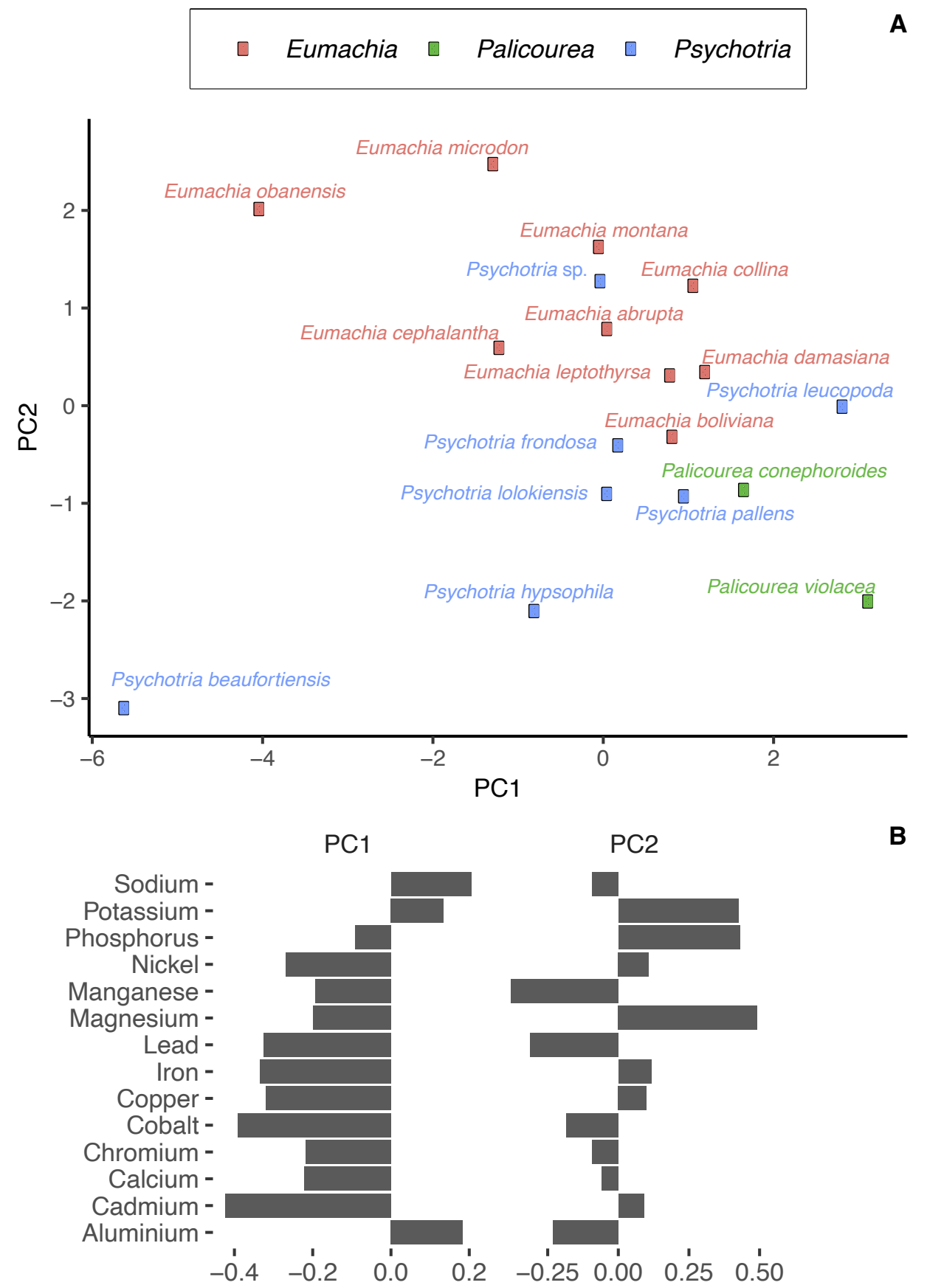

Figure 2. Results of principal components analysis: A, biplot of foliar concentrations of 14 elements; $B$, correlation between the axis score and elemental concentration for 18 species from three Rubiaceae genera. PC, principal component. 
Eumachia acuifolia (Jansen et al., 2000), it is clear that the accumulation of aluminium is not a universal or even frequent phenomenon in Eumachia.

The comparison between Eumachia and Psychotria foliar Al concentration found no consistent differences. One of the seven species of Psychotria tested was a clear aluminium hyperaccumulator. Notably, Psychotria pallens has foliage that dries a pale green rather than red-brown, which is the general pattern in Psychotria sensu stricto. Although only two species of Palicourea were analysed, both were found to be aluminium accumulators. One had the highest foliar aluminium concentrations recorded in this study and the other was well over the accumulator threshold. Aluminium hyperaccumulation has been previously reported in species of Palicourea (Chenery, 1948; Jansen et al., 2000), but its prevalence in the genus is considerably greater than this, because many of the species listed in these reports have subsequently been transferred to Palicourea. So, for instance, of the 24 species of Psychotria and Cephaelis that Chenery (1948) reported as aluminium hyperaccumulators, only three are now recognised in Psychotria and the rest have all been relocated to Palicourea.

The taxonomic changes in these Rubiaceae genera have largely been driven by studies of phylogenetic relationships using molecular data, although the morphological overview of Taylor (1996) presaged much of the rearrangement. Phylogenetic analyses have shown that Psychotria, as traditionally recognised, contained disparate elements representing various clades (Nepokroeff et al., 1999; Razafimandimbison et al., 2014). The ongoing reorganisation has resulted in considerable change to the systematics of this part of the Rubiaceae. These include the recognition of the tribe Palicoureeae as sister to Psychotrieae (Robbrecht \& Manen, 2006), the transfer of much of the heterogeneous Psychotria subgenus Heteropsychotria to Palicourea, and the recognition of Eumachia as a large pantropical genus in the Palicoureeae. The currently accepted phylogeny for the genera in this clade of the Rubiaceae is shown in Figure 3.

Aluminium accumulation is widely known in the Rubiaceae (Jansen et al., 2000), although apparently commoner in subfamily Rubioideae than in subfamily Cinchonoideae. Our results, and those of others (Chenery, 1948; Haridasan, 1982; Jansen et al., 2000), confirm the presence of aluminium accumulation in the sister tribes Psychotrieae and Palicoureeae. The prevalence of aluminium accumulation seems mixed among the genera of these tribes. Palicourea has many species that are aluminium hyperaccumulators, but its cotribalist Eumachia is less frequently found to have tissues with abundant aluminium. Interestingly, Palicourea species also tend to have leaves that dry with a greenish hue (Berger, 2018), and this is listed as a character of the Palicoureeae in general (Stevens, continuously updated). Palicourea species often have blue fruits (Taylor \& Steyermark, 2004; Berger, 2018), which is a known correlate of aluminium hyperaccumulation (Chenery, 1948), but in Eumachia the fruits generally ripen orange-red (Taylor et al., 2017). It seems likely, therefore, that an inherent tolerance to relatively high internal aluminium concentrations is widespread and 


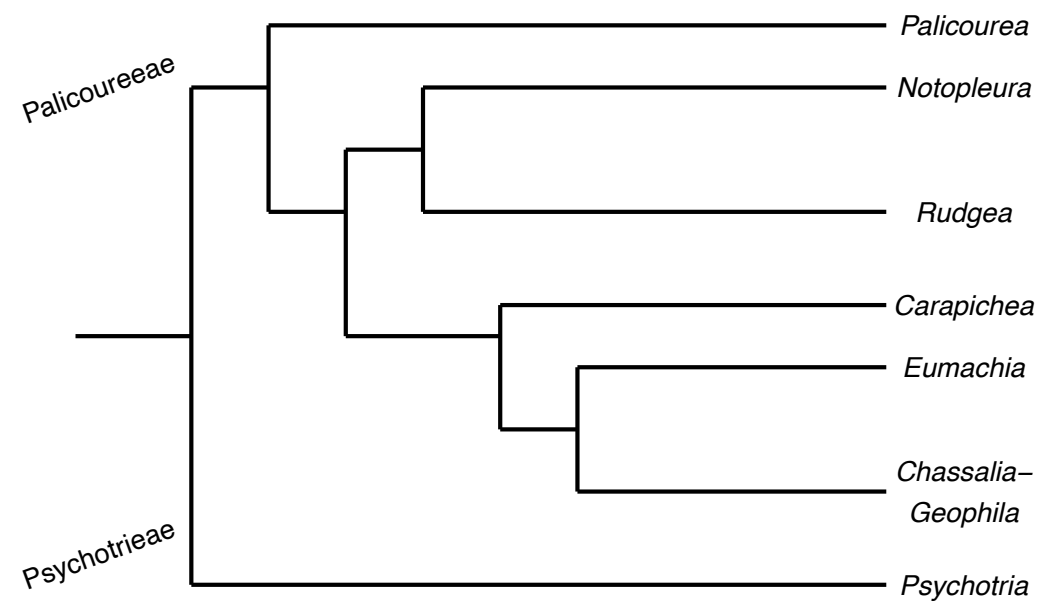

Figure 3. Phylogenetic relationships of the genera in the sister tribes Psychotrieae and Palicoureeae of the Rubiaceae (after Razafimandimbison et al., 2014).

probably long established in this branch of the Rubiaceae - perhaps unsurprising for a set of genera that are very diverse across the lowland tropics, and that often grow on acid and aluminium-rich soils. It may be that in the Palicoureeae the tendency for leaves to dry green is related to the physiology of mineral uptake and deployment in the tissues, but clearly in Eumachia it is not always linked to aluminium accumulation.

Interestingly, the overall stoichiometry of foliar elemental concentrations appeared to show some discrimination at the generic level, with species of Eumachia exhibiting relatively high concentrations of the physiologically abundant elements $\mathrm{Mg}, \mathrm{K}$ and $\mathrm{P}$ compared with species of Psychotria and Palicourea. Two of the species of Psychotria also had relatively high foliar $\mathrm{Mn}$ concentrations, accentuating the discrimatory power of the second principal component in the PCA. Most Eumachia specimens sampled had leaves with a very thin, membranous texture. The Psychotria/Palicourea specimens tended to vary from chartaceous to subcoriaceous in leaf texture rather than the tissue-thin laminas of Eumachia. A higher cell wall to cytoplasm ratio in the Psychotria/Palicourea specimens might be the explanation for the generally lower concentrations of physiologically important elements than in Eumachia species.

Clearly, many questions remain unanswered and there is considerable scope for further comparisons within and among widespread tropical genera such as Eumachia and Psychotria.

\section{Acknowledgements}

We thank David McKendry (MMU) for running the ICP-OES analysis and Martin Cheek (K) for helpful comments on the manuscript. 


\section{References}

Andersson L. 2001. Margaritopsis (Rubiaceae, Psychotrieae) is a pantropical genus. Systematics and Geography of Plants. 71(1):73-85. https://doi.org/10.2307/3668754

Barrabé L, Buerki S, Mouly A, Davis AP, Munzinger J, Maggia L. 2012. Delimitation of the genus Margaritopsis (Rubiaceae) in the Asian, Australasian and Pacific region, based on molecular phylogenetic inference and morphology. Taxon. 61(6):1251-1268. https://doi.org/10.1002/ tax.616007

Berger A. 2018. Synopsis and typification of Mexican and Central American Palicourea (Rubiaceae: Palicoureeae), part I: the entomophilous species. Annalen des Naturhistorischen Museums in Wien. Serie B für Botanik und Zoologie. 120:59-140. https://www.jstor.org/stable/26335282

Chenery EM. 1948. Aluminium in plants and its relation to plant pigments. Annals of Botany. 12(2):121-136. https://doi.org/10.1093/oxfordjournals.aob.a083177

Davis AP, Bridson D, Jarvis C, Govaerts R. 2001. The typification and characterization of the genus Psychotria L. (Rubiaceae). Botanical Journal of the Linnean Society. 135(1):35-42. https://doi. org/10.1006/bojl.2000.0390

Haridasan M. 1982. Aluminium accumulation by some cerrado native species of central Brazil. Plants and Soil. 65:265-273.

Jansen S, Dessein S, Piesschaert F, Robbrecht E, Smets E. 2000. Aluminium accumulation in leaves of Rubiaceae: systematic and phylogenetic implications. Annals of Botany. 85(1):91-101. https://doi. org/10.1006/anbo.1999.1000

Metali F, Salim KA, Burslem DFRP. 2011. Evidence of foliar aluminium accumulation in local, regional and global datasets of wild plants. New Phytologist. 193(3):637-649. https://doi. org/10.1111/j.1469-8137.2011.03965.x

Nepokroeff M, Bremer B, Sytsma KJ. 1999. Reorganization of the genus Psychotria and tribe Psychotrieae (Rubiaceae) inferred from ITS and rbcL sequence data. Systematic Botany. 24(1):5-27. https://doi.org/10.2307/2419383

R Core Team. 2020. R: A language and environment for statistical computing. Vienna: R Foundation for Statistical Computing. https://www.R-project.org/

Razafimandimbison SG, Taylor CM, Wikström N, Pailler T, Khodabandeh A, Bremer B. 2014. Phylogeny and generic limits in the sister tribes Psychotrieae and Palicoureeae (Rubiaceae): evolution of schizocarps in Psychotria and origins of bacterial leaf nodules of the Malagasy species. American Journal of Botany. 101(7):1102-1126. https://doi.org/10.3732/ajb.1400076

Robbrecht E, Manen JF. 2006. The major evolutionary lineages of the coffee family (Rubiaceae, Angiosperms). Combined analysis (nDNA and cpDNA) to infer the position of Coptosapelta and Luculia, and supertree construction based on rbcL, rps16, $\operatorname{trnL}-\operatorname{trnF}$ and atpB-rbcL data. A new classification in two subfamilies, Cinchonoideae and Rubioideae. Systematics and Geography of Plants. 76(1):85-145. http://www.jstor.org/stable/20649700

Stevens PF. Continuously updated. Angiosperm Phylogeny Website, version 14. http://www.mobot.org/ MOBOT/research/APweb/ [Accessed 11 June 2019.] 
Taylor CM. 1996. Overview of the Psychotrieae (Rubiaceae) in the Neotropics. Opera Botanica Belgica. 7:261-270.

Taylor CM, Steyermark JA. 2004. 63. Palicourea Aubl., Hist. PI. Guiane 172, pl. 66. 1775. In: Steyermark JA, Berry PA, Yatskievych K, Holst BK, editors. Flora of the Venezuelan Guayana, Volume 8 Poaceae-Rubiacae. St Louis: Missouri Botanical Garden Press. pp. 680-691.

Taylor CM, Razafimandimbison SG, Barrabé L, Jardim JG, Barbosa MRV. 2017. Eumachia expanded, a pantropical genus distinct from Psychotria (Rubiaceae, Palicoureeae). Candollea. 72:289-318. https://doi.org/10.15553/c2017v722a6

\section{Appendix}

\section{LIST OF SPECIMENS ANALYSED FOR THE STUDY}

All are from the herbarium collection of the Royal Botanic Gardens, Kew (K).

Eumachia abrupta (Hiern) J.H.Kirkbr.

TANZANIA. Uzungwa Mountain NP, stream west of Kilombaro village, 12 xi 1997, P.A. \& W.R.Q. Luke 5151.

Eumachia boliviana (Standl.) Delprete \& J.H.Kirkbr.

PERU. Coronel Portillo, Chara del Sr Cesar Vela, 25 x 1972, J. Sibunke V. 5461.

Eumachia cephalantha (Müll.Arg.) Delprete \& J.H.Kirkbr.

BRAZIL. Sao Paulo: Piracicaba, estrada para Limeira, 14 vii 1993, V.C. Souza et al. 6001.

Eumachia collina (Labill.) Barrabé, C.M.Taylor \& Razafim.

New CaledoniA. Exploitation forestiere Guiraud piste en direction de Mt Ades (800-850 m), sol ferallitique sur peridotites, 25 iii 1988, Jaffre 2951.

Eumachia damasiana (Sohmer) Barrabé, C.M.Taylor \& Razafim.

PAPUA NeW GuineA. New Britain: north end of Lake Daketana on Willhaumez Peninsula, 30 v 1973, R.S. Isles et al. NGF 32277.

Eumachia leptothyrsa (Miq.) Barrabé, C.M.Taylor \& Razafim.

PAPUA NeW GuINEA. Madang Province: Ramu Subprovince, Walium Station, 20 iv 1979, Sohmer \& Katik LAE 75127.

Eumachia microdon (DC.) Delprete \& J.H.Kirkbr.

PANAMA. OIS, 16 vi 1924, L.A.M. Riley SERA 149.

Eumachia montana (Blume) I.M.Turner

INDONESIA. Sumbawa: 1927, I. Rensch 593.

Eumachia obanensis (Wernham) Razafim. \& C.M.Taylor

CAMERoon. Prov. Sud-Oeust: Dept Fako, Bakingili 50-300 m trail to Mt Cameroon, 25 vii 1984, S.A.

Thompson \& J.E. Rawlins 1662.

Palicourea conephoroides (Rusby) C.M.Taylor

Peru. Pasco: Oxapampa, Distrito Palcazu, Parque Nacional Yonachagu-Chemillen, Bosque el mirador, 750-820 m, 14 v 2003, A. Monteagudo et al. 5228. 
Palicourea violacea (Aubl.) A.Rich.

PANAmA. El Valle de Anter alt. 1000 m, 16 vi 1946, P.H. Allen 3536.

Psychotria beaufortiensis Valeton ex Sohmer

INDONESIA. North New Guinea, Cycloop Mountains between Nefor and the coast, vi 1938, E. Meijer-Drus 29.

\section{Psychotria frondosa S.Moore}

New Caledonia. Col d'Amien, Mont Pembai 800 m, foret humide schistes, 14 iv 1976, H.S. McKee 31039.

Psychotria hypsophila K.Schum. \& K.Krause

CAmeroon. Proposed Ebo NP, near the Njuna River, 7 x 2015, M. Alvarez 30.

Psychotria leucopoda E.M.A.Petit

TANZANIA. Kwamngumi FR, 350 m, 14 xi 1986, Ruffo \& Mmari 1980.

\section{Psychotria lolokiensis S.Moore}

Papua New Guinea. Near south-east side of Little Mt Lowes, c. 16 miles north of Port Morseby, 25 iv 1967, R. Pullen 6813.

\section{Psychotria pallens Gardner}

BRAZIL. Rio de Janeiro, 24 vii 2012, J.A. Oliveira et al. 168.

\section{Psychotria sp.}

INDONESIA. Sumbawa: Mata, 2 i 1910, J. Elbert 4106. 